\title{
Biofilm Formation as a Complex Result of Virulence and Adaptive Responses of Helicobacter pylori
}

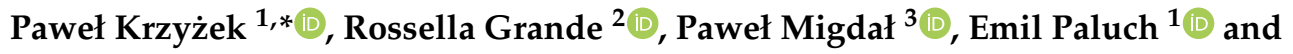 \\ Grażyna Gościniak ${ }^{1}$ (1)
}

1 Department of Microbiology, Faculty of Medicine, Wroclaw Medical University, 50-368 Wroclaw, Poland; emil.paluch@umed.wroc.pl (E.P.); grazyna.gosciniak@umed.wroc.pl (G.G.)

2 Department of Pharmacy, University "G. d'Annunzio" of Chieti-Pescara, Via dei Vestini, 31, 66100 Chieti, Italy; r.grande@unich.it

3 Department of Environment, Hygiene and Animal Welfare, Wroclaw University of Environmental and Life Sciences, 51-630 Wroclaw, Poland; pawel.migdal@upwr.edu.pl

* Correspondence: krojcerpawel@gmail.com

Received: 27 November 2020; Accepted: 17 December 2020; Published: 18 December 2020

check for updates

\begin{abstract}
Helicobacter pylori is a bacterium that is capable of colonizing a host for many years, often for a lifetime. The survival in the gastric environment is enabled by the production of numerous virulence factors conditioning adhesion to the mucosa surface, acquisition of nutrients, and neutralization of the immune system activity. It is increasingly recognized, however, that the adaptive mechanisms of $H$. pylori in the stomach may also be linked to the ability of this pathogen to form biofilms. Initially, biofilms produced by $H$. pylori were strongly associated by scientists with water distribution systems and considered as a survival mechanism outside the host and a source of fecal-oral infections. In the course of the last 20 years, however, this trend has changed and now the most attention is focused on the biomedical aspect of this structure and its potential contribution to the therapeutic difficulties of H. pylori. Taking into account this fact, the aim of the current review is to discuss the phenomenon of $H$. pylori biofilm formation and present this mechanism as a resultant of the virulence and adaptive responses of $H$. pylori, including morphological transformation, membrane vesicles secretion, matrix production, efflux pump activity, and intermicrobial communication. These mechanisms will be considered in the context of transcriptomic and proteomic changes in $\mathrm{H}$. pylori biofilms and their modulating effect on the development of this complex structure.
\end{abstract}

Keywords: Helicobacter pylori; biofilm; antibiotic resistance; outer membrane vesicles; coccoid forms; efflux pumps; biofilm matrix; quorum sensing

\section{The Issue of Biofilm Formation in the Biomedical Sector}

Despite their small sizes, microorganisms are characterized by exceptional complexity and diversity [1]. Classically, microorganisms can appear as free-swimming (planktonic) forms or multicellular clusters, referred to as biofilms [2-6]. Microbial biofilm is defined as a structured consortium of cells immersed in a self-produced matrix [2,6]. It is worth mentioning, however, that the biofilm may also include host components, e.g., fibrin, antibodies, platelets, or leukocytes. Biofilms can be attached to an abiotic or biotic surface, but they can also constitute a mobile, non-adhered structure floating in culture broth or body fluids [2,3]. Because of the proximity of microbial cells and their physical, metabolic, and social interactions, the biofilm growth differs significantly from the planktonic lifestyle [2-5].

Probably, the first observer of biofilms was Anthony van Leeuwenhoek (1632-1723), who, using a primitively constructed microscope, noticed microbial aggregates in oral samples [7]. 
The term "biofilm" was introduced by J. W. Costerton, in 1985, in a brief report presenting microscopic photos of Pseudomonas aeruginosa microcolonies residing in sputum samples of a cystic fibrosis patient. Although the presence of biofilms has its positive aspect in many ecosystems, these structures also exert their negative impact in the biomedical sector $[4,8]$. The ability of biofilm cells to survive in the environment with elevated concentrations of antimicrobial substances is termed "recalcitrance" and is a hallmark of treatment failures. In addition, biofilm cells have significantly lower sensitivity to unfavorable physicochemical factors and the activity of the immune system. The reduced susceptibility of biofilms results not only from the processes of passive tolerance to antimicrobials (decreased metabolism, matrix limiting the penetration of antibiotics, or presence of persister cells), but also from the processes of active increase in the number of resistant microorganisms (intensification of horizontal gene transfer (HGT) or induction of the hypermutable state) [4].

In association with the prevalence of biofilm formation and its negative impact on the infections treatment, in 2014, the European Society of Clinical Microbiology and Infectious Diseases (ESCMID) developed recommendations for microbiologists and physicians to improve the diagnosis of the most common infections accompanied by the biofilm presence [2]. The list of such diseases is wide and continues to grow, including: chronic otitis media/sinuses, endocarditis, lung infections associated with cystic fibrosis, urinary tract infections, vaginosis, osteomyelitis, chronic wound infections, catheter-related infections, and cancers of bile ducts and digestive system $[4,5,8]$. In the context of the last type of infections, attention should be focused strongly on spiral, Gram-negative rods colonizing the gastric mucosa-Helicobacter pylori $[9,10]$.

H. pylori has the ability to reside in the stomach for many years, often for a lifetime [11]. Although the presence of this bacterium may be associated with a number of gastrointestinal diseases, including gastric ulcers and cancers [12-14], more and more often the protective role against developing extra-gastric diseases, such as allergy, asthma, inflammatory bowel disease, or multiple sclerosis, is indicated [15-17]. Survival of H. pylori in an unfavorable, gastric niche is enabled by an intensive urease secretion, a spiral shape, presence of numerous adhesins, and the production of cytotoxic proteins, e.g., vacuolating cytotoxin A (VacA) and cytotoxin-associated gene A (CagA) [18]. It is increasingly recognized, however, that the adaptive mechanisms of $H$. pylori in the stomach may also be linked to the ability of this pathogen to form biofilms [19]. Nevertheless, this theme is still rarely discussed by scientists and despite the availability of results from original articles the number of reviews and exhaustion of $H$. pylori biofilm topic are unsatisfactory.

Taking into account the above facts, the aim of the current review is to discuss the phenomenon of $H$. pylori biofilm formation and present this mechanism as a resultant of the virulence and adaptive responses of $H$. pylori, including morphological transformation, membrane vesicles secretion, matrix production, efflux pump activity, and intermicrobial communication. These mechanisms will be considered in the context of transcriptomic and proteomic changes in H. pylori biofilms and their modulating effect on the development of this complex structure.

\section{Characteristics of $\boldsymbol{H}$. pylori Biofilms Produced in Laboratory Conditions}

The first study showing the ability of H. pylori to form biofilm took place in 1999 [20]. Since then, the knowledge on this subject has expanded significantly, and the presence of $H$. pylori biofilms has been demonstrated in numerous in vitro studies using plastic or glass surfaces [21-25], cell cultures [26,27], gastric biopsies from animals [28] or humans [29,30], and even vegetable surfaces [31] or water distribution tanks [32-34]. It is worth noting that initially $H$. pylori biofilms were strongly associated by scientists with water distribution systems and were considered as a survival mechanism outside the host and a source of fecal-oral infections [35]. In the course of the last 20 years, however, this trend has changed and now the most attention is focused on the biomedical aspect of this structure and its potential contribution to the therapeutic difficulties of $H$. pylori [22,23,36-39].

Under laboratory conditions, $H$. pylori biofilm may be formed during both liquid or solid cultures. In the first case, there are several types of biofilms that can develop under such conditions, i.e., a biofilm 
formed on the liquid-air surface (most often as a macroscopically visible ring, possibly accompanied by a pellicle development) [22,40-42], a biofilm formed as sediment of cells adhered to a solid surface (cells are completely immersed in the medium) [21,22,41], and a biofilm present as multicellular aggregates freely drifting in the liquid phase (cells are immersed in the medium but do not sink to the bottom) [22,41,43]. In the case of culture on a solid substratum, the so called "colony biofilm" [38,39] or "lawn biofilm" [44] are most often indicated. Since the vast majority of research on H. pylori biofilms focuses only on these formed during liquid culture, the data discussed in this review will mainly spotlight such types of bacterial communities.

Environmental and cultivation conditions constitute parameters that may affect the process of H. pylori biofilm formation in the laboratory $[21,22,24,45,46]$. Adhesion of $H$. pylori to the surface, a first stage conditioning the biofilm formation, largely depends on the flow rate (inversely associated with the adhesion) and the surface charge (the negative surface charge is preferred), while the ambient temperature does not significantly affect the adhesion [24,45]. The $\mathrm{pH}$ of the environment is a factor that modulates the subsequent processes of biofilm formation. It was found that with decreasing $\mathrm{pH}$, the ability of H. pylori to produce this structure declined, especially at very low values [22]. Exposure of the preformed biofilm to a slightly acidified environment $(\mathrm{pH}=5.5)$ had no effect on the $H$. pylori biofilm, but still, a highly acidified medium $(\mathrm{pH}=3)$ eliminated this structure. These results indicate the existence of a regulator of $H$. pylori that senses changes in the $\mathrm{pH}$ of the local environment and modulates the ability of this bacterium to form biofilm, especially in its early stages. An example of this type of regulator is ArsRS, which conditions the maintenance of H. pylori in a planktonic form in the strongly acidic environment of gastric juice [41]. Its more detailed characteristics and influence on the formation of $H$. pylori biofilm can be found in later parts of this article ("Transcriptomic and proteomic analysis of $H$. pylori biofilm forms"). Apart from environmental conditions, the chemical composition of the culture medium and the incubation period are other important parameters influencing the biofilm of $H$. pylori [21,46]. Laboratory experiments showed that the low serum content $(2 \%)$ and the three-day culture were optimal for the maximal growth of H. pylori biofilms [21]. Extending the cultivation time does not increase the size of the biofilm, and sometimes even reduces it [21,22,41,47], indicating the dynamics of biofilm production and the participation of dispersion in the late stages of biofilm maturation [48].

\section{Transcriptomic and Proteomic Analysis of Biofilm H. pylori Forms}

The development of biofilm structure and the transition from planktonic to biofilm phase are influenced by changes in the expression and translation of $H$. pylori genes. These changes were determined experimentally using 'omics' techniques (transcriptomics, proteomics, and metabolomics), and despite some differences between the results obtained by independent research teams, it is still possible to identify the most important features of the biofilm forms of this bacterium. In these studies, an increased expression has been demonstrated for: global pleiotropic regulators [21,22,49,50], adhesins (especially outer membrane proteins from the Hop and Hom family) [21,22,51,52], lipopolysaccharide (LPS) [21,22,51], efflux pumps [22,37-39,53-55], flagella proteins [21,43,51], components of T4SS systems [21,22,43,51], enzymes regulating $\mathrm{pH}$ (e.g., urease or arginase) [43,56] and responsible for obtaining alternative energy sources (e.g., hydrogenase) [22,43], proteins related to the cell wall rearrangement [22,43], and proteins of the toxin-antitoxin system [47] (Figure 1). Covering the components for which a decrease in the expression in biofilm H. pylori forms has been shown, these were factors involved in metabolism [21,22,57], translation [21,22], and quorum sensing related to the autoinducer-2 (AI-2) activity [22,46,48,55,58,59] (Figure 1). The influence of the transition of H. pylori into the biofilm form on the amount of antioxidant proteins is difficult to determine, because Yang et al. [56] and Shao et al. [43] showed their increase, while Hathroubi et al. [22] showed an opposite situation. It is possible that this difference results from the type of analyzed biofilm. Yang et al. [56] and Shao et al. [43] studied biofilm cells that were exposed to oxidative stress (air-liquid biofilms or these formed as microaggregates in the medium), while the 
one studied by Hathroubi et al. [22] was a sedentary biofilm produced at the bottom of wells, where the oxygen concentration is significantly lower.

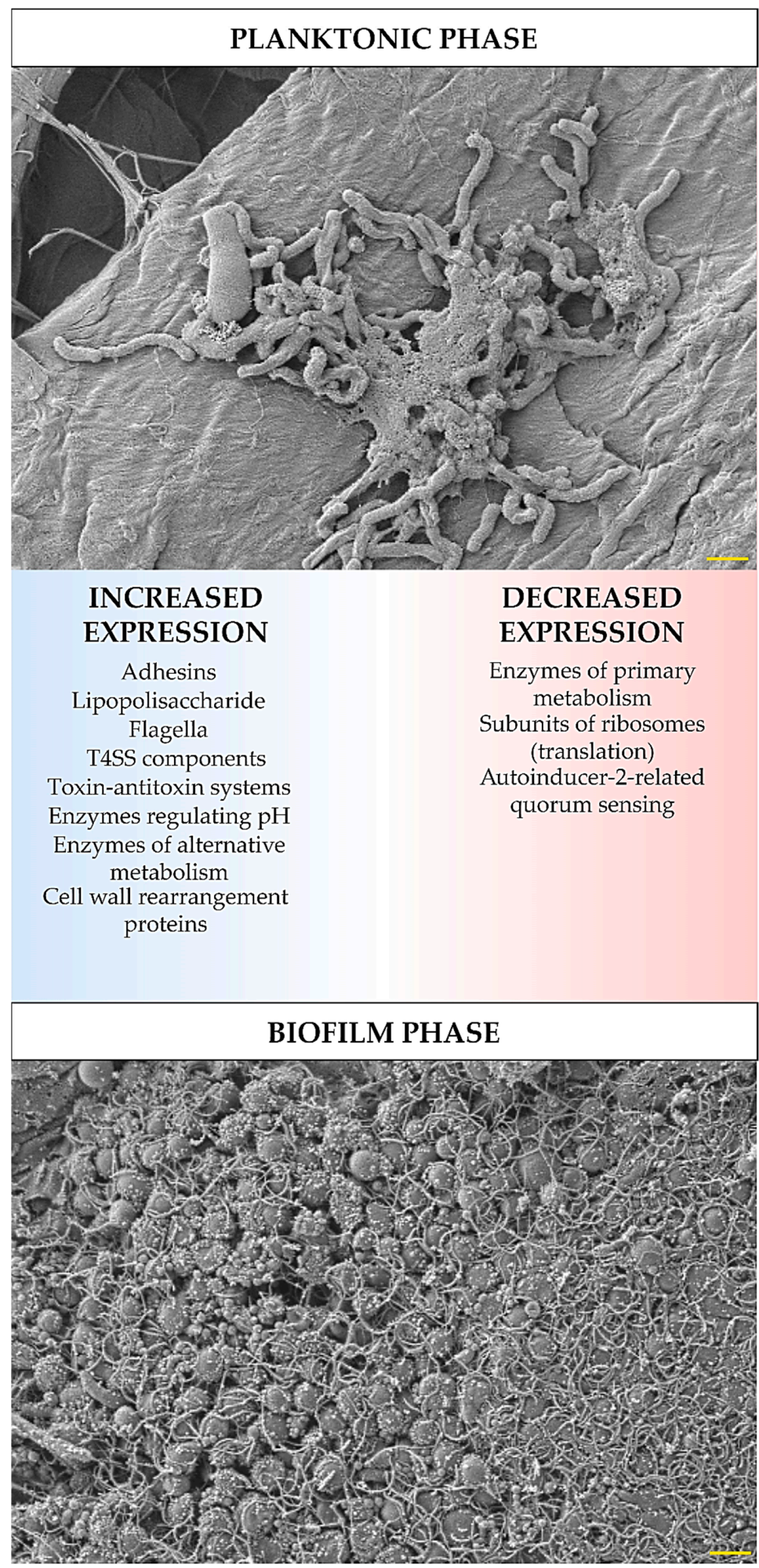

Figure 1. Diagram showing transcriptomic/proteomic changes in $H$. pylori cells during the transition from planktonic to biofilm phase. The scale bar shows $1 \mu \mathrm{m}$.

Among the proteins mentioned above, it is worth paying attention to the production of global regulators of $H$. pylori physiology, because they will influence the expression of other genes under 
their control. In general, negative regulators bind to the promoter, reducing the attachment of RNA polymerase and lowering the expression of specific genes. In the case of positive regulators, binding is observed in the promoter's upstream region, which determines the recruitment of polymerase and the increase in gene expression $[60,61]$.

Shao et al. [43] showed that aconitase production increases in the biofilm phase. Aconitase acts as a pleiotropic regulator supervising antioxidant functions, motility and production of flagella, as well as the activity of some enzymes (urease and hydrogenase) [62]. It was established that the high activity of $H$. pylori hydrogenase is a feature of strains with a high carcinogenic potential [63]. Through hydrogenase, this bacterium can use molecular hydrogen $\left(\mathrm{H}_{2}\right)$ to switch to the chemolithoautotrophic mode and use the energy from this process to bind $\mathrm{CO}_{2}$ [64]. Hydrogenase is also crucial for the functioning of the T4SS systems, both Cag-T4SS (involved in cytotoxicity and oncogenicity) and ComB-T4SS (involved in DNA transformation) [63]. It is worth noting that the ComB system is inactive at acidic $\mathrm{pH}$ and is stimulated in the environment with $\mathrm{pH}>6.5$, indicating that the transformation process takes place in close proximity to the gastric mucosa [65] and explaining the increase in urease production during biofilm formation (when microbial transformation is strongly intensified) [56].

The increased expression of H. pylori regulators during the transition to the biofilm phase, including HspR, HrcA, CrdR, and RsfS, was also demonstrated by the team of Hathroubi et al. [21,22]. HspR and HrcA have a positive effect on the production of flagella and selected adhesins, while negative on the chaperone proteins (GroES, GroEL, and DnaK) [66,67]. CrdR responds in H. pylori to the nitrosic stress (exposure to NO) [49]. It was experimentally found that flagellar components, iron transporter (fecA, HP0807) and efflux pump ( $g \ln P, \mathrm{HP1169})$ were among the genes with the highest induction controlled by CrdR [49]. For RsfS, participation in the inhibition of large and small subunits of ribosomes has been shown and, as a consequence, a reduction of protein synthesis (one of the most energy-consuming physiological processes) [68]. This mechanism seems to explain the observations of Hathroubi et al., who noticed a decrease in the expression of translation genes during the transition of H. pylori to the biofilm phase [21,22].

Apart from global regulators having a positive effect on the production of biofilm, it is also worth paying attention to the existence of the ArsRS regulator, which is a two-component system negatively associated with the production of this structure [41,52]. For ArsRS, the pH-dependent effect is indicated, during which exposure to the acidic $\mathrm{pH}$ of gastric juice inhibits the expression of genes related to biofilm formation, while in an environment with a neutral $\mathrm{pH}$ the effect of this system is inhibited [41]. The $\triangle a r s S$ mutants showed a higher degree of adhesion to the surface and more intensive biofilm production (twice after 1-2 days and four times after 3 days of incubation than the wild-type strain) [41,52]. Moreover, in these mutants, an increase in the expression of genes encoding outer membrane proteins was noticed; these included alpB (omp21/homB), sabA (omp17/hopP), labA (omp2/hopD), and hopZ (omp1) [52,69].

The presented data show that global regulators can significantly influence the physiology of $H$. pylori and determine the transition from planktonic to biofilm form and vice versa.

\section{Phenotypic Variability as a Modulator of H. pylori Biofilm Structure}

Biofilm of $H$. pylori is a highly complex structure, consisting of morphologically heterogeneous bacterial cells immersed in the matrix (Figure 2), in which the presence of intercellular spaces and pores (water channels) is noticeable (Figure 3) $[21,22,40,41,56,58]$. In the H. pylori biofilm matrix, apart from bacteria, many cell structures can be found, including outer membrane vesicles (OMVs), flagella, and pili (most likely a component of $t f 54$-T4SS, a system associated with HGT [22]) (Figure 4). Both the morphotype of bacteria and the individual structural/extracellular components mentioned above can influence the process of biofilm formation and its architecture. Therefore, the function of each in the context of $H$. pylori transition to the biofilm phase will be described in the next sections of this review article. 

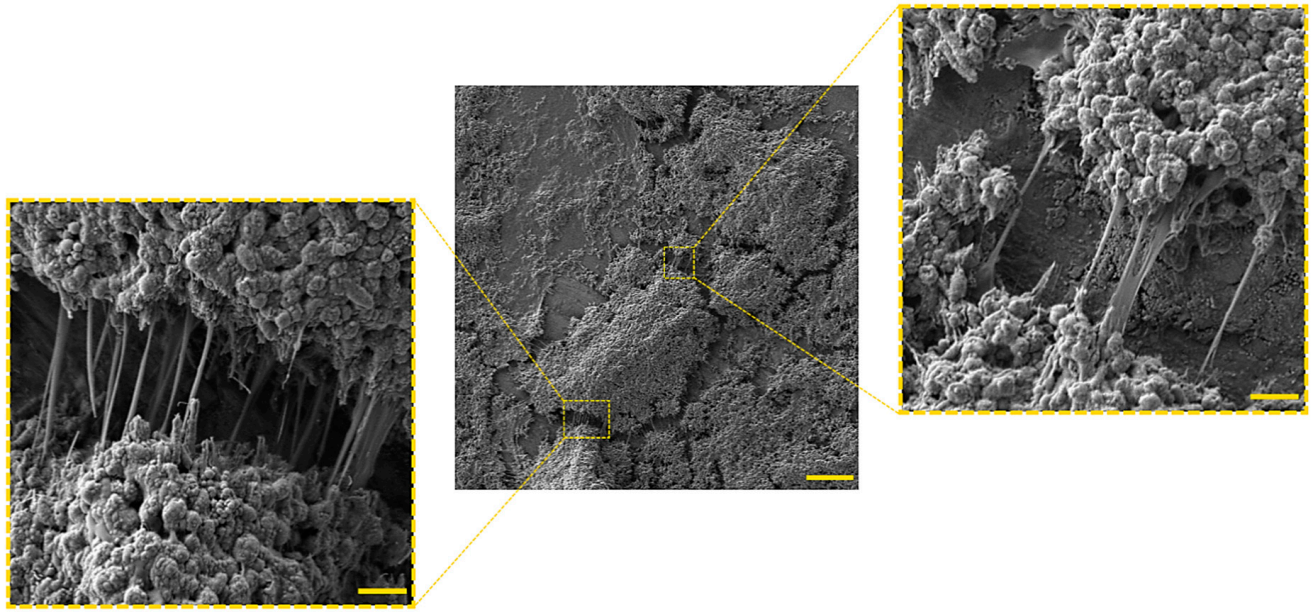

Figure 2. Representative photos showing a seven-day-old sediment H. pylori Tx30a biofilm along with the present exopolysaccharide matrix. The scale bar shows $40 \mu \mathrm{m}$ for a central picture and $1 \mu \mathrm{m}$ for magnified fragments of the photography.

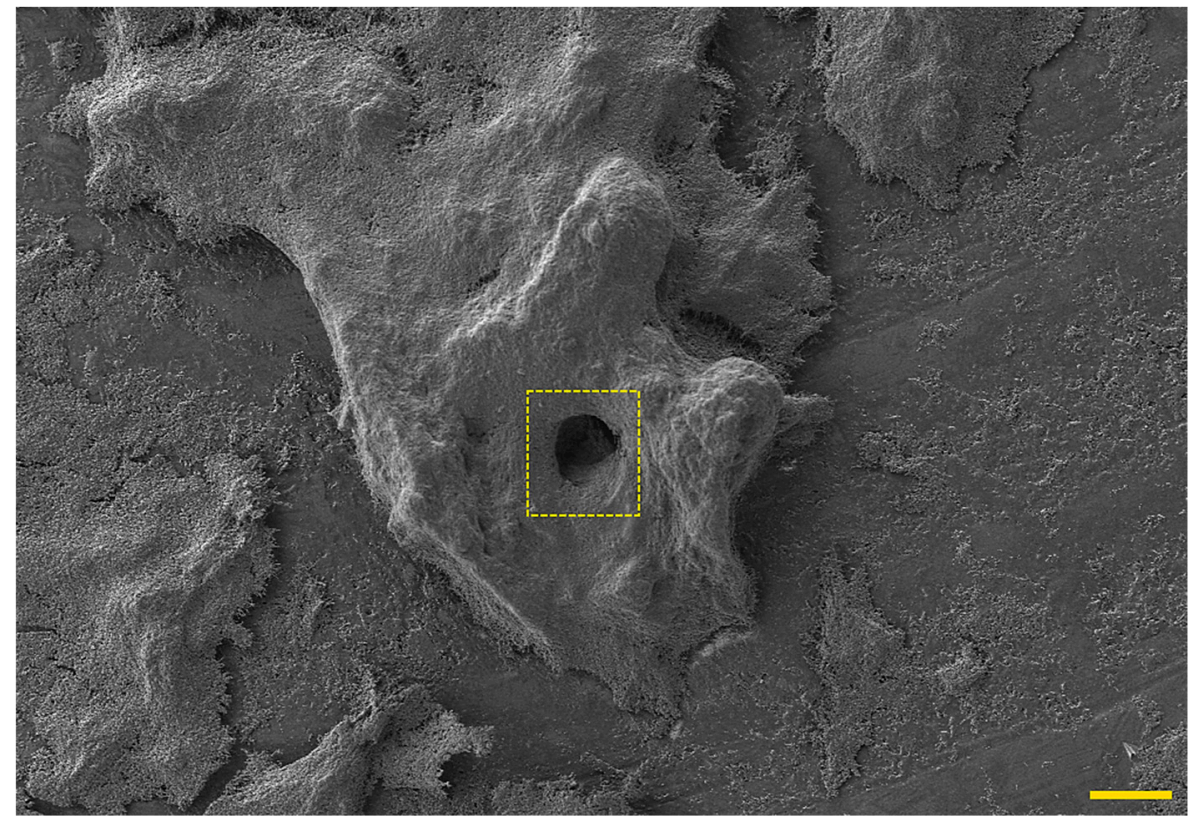

Figure 3. Representative photo of a mature seven-day-old H. pylori Tx30a biofilm formed on the liquid-air surface, in which the presence of a large water channel (marked with a dashed square) running through the biofilm structure can be seen. The scale bar shows $40 \mu \mathrm{m}$. 


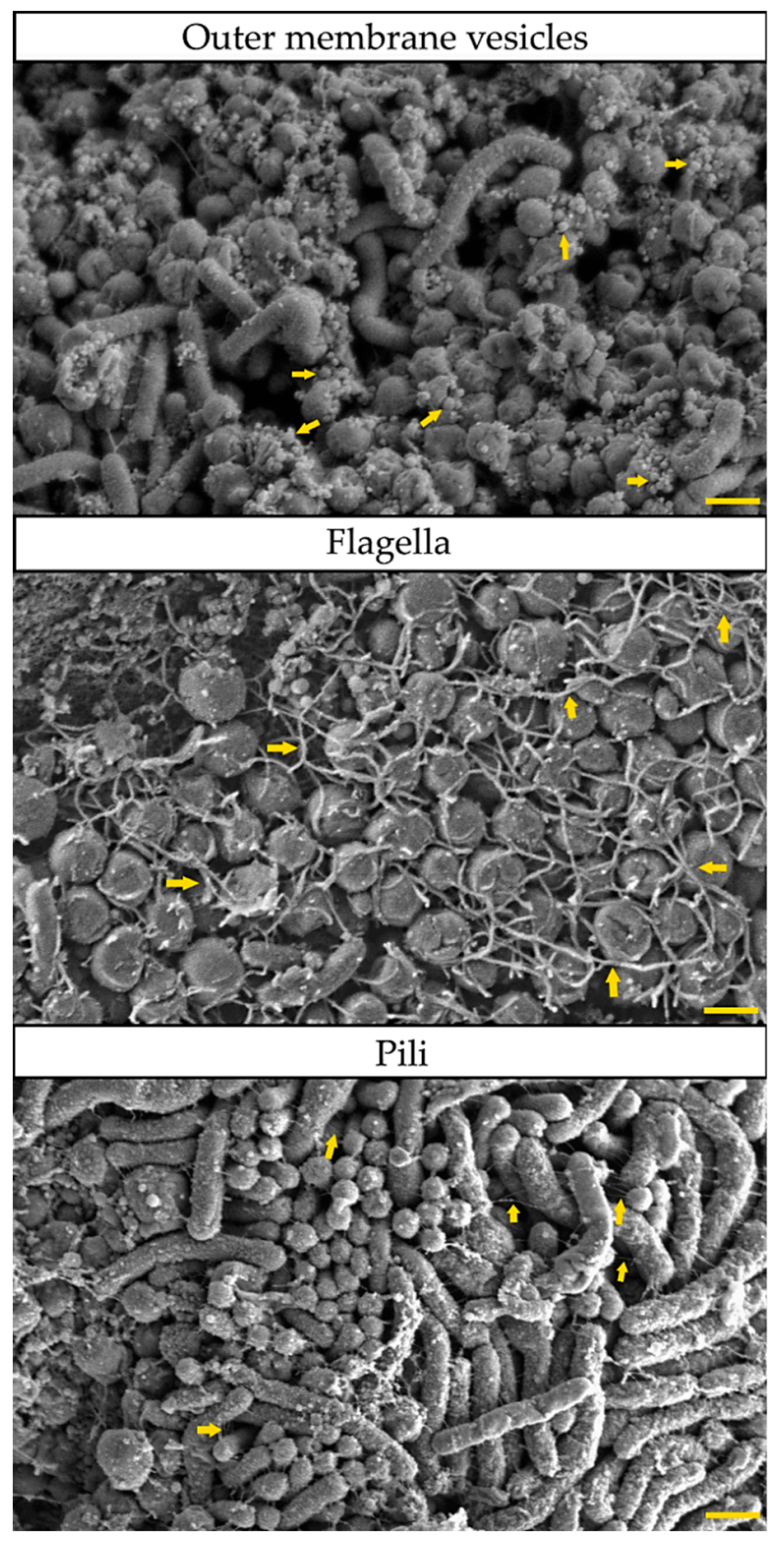

Figure 4. Representative photos of cellular and extracellular structures involved in the formation of H. pylori biofilm (based on multidrug resistant, clinical H. pylori 8064). From above: outer membrane vesicles (OMVs) visible as tiny, oval structures of 50-300 nm diameters; flagella noticeable as long structures entwining bacterial cells; and pili seen as very fine, thin filaments connecting bacteria cells. All the above-mentioned structures are marked with yellow arrows. The scale bar shows $1 \mu \mathrm{m}$.

\subsection{Coccoid Forms}

In the initial stages of biofilm formation, $H$. pylori is in a spiral form $[45,56,58]$. This morphological form is highly mobile and associated with the colonization of new niches [11,70]. After effective adhesion to the surface and multiplication, a morphological transformation occurs, which is accompanied by the creation of high shapes heterogeneity (spiral, rod-shaped, curved, coccoid, and filamentous forms) [70]. However, in the case of prolonged cultivation, all cells in the biofilm finally transform to a coccoid form, for which participation in survival and higher tolerance to adverse environmental factors is indicated [71,72]. It is worth mentioning that the morphological transition of $H$. pylori to coccoid forms is accompanied by numerous physiological changes, including reduction of cell size, 
limitation of intracellular ATP, changes in cell membrane potential, and generation of endogenous oxidative stress-dependent modifications in the structure of DNA and proteins [71]. These processes are associated with the acquisition of a viable but non-culturable (VBNC) phenotype by spherical $H$. pylori forms and loss of culturability [73], although there are also reports showing the possibility of the existence of spherical $H$. pylori forms in a culturable form [74].

A recently published report by Kadkhodaei et al. [74] has described an H. pylori strain with changed phenotype (overproduction of mucus on agar plates occurring only in a spherical morphotype; hence, it was defined as a mucoid-coccoid strain). In contrast to the parental strain with a typical phenotype and high antibiotic sensitivity, from which the H. pylori mucoid-coccoid strain was derived, the latter was resistant to all tested antibiotics. This shows the link between the overproduction of the extracellular matrix and the presence of spherical $H$. pylori forms with tolerance to antimicrobial substances.

Transcriptomic analysis by Poursin et al., determining the effect of the morphology change of H. pylori on the spoT status, showed 30 times higher expression of this gene in coccoid forms than in their spiral counterparts [75]. SpoT is a bifunctional enzyme responsible for both the synthesis and degradation of (p)ppGpp (referred to as alarmone). For SpoT, it has been shown that this enzyme contributes to the biofilm formation and supervision of efflux pumps, i.e., proteins associated with antimicrobial removal and resistance generation $[39,76]$. A detailed description of the involvement of efflux pumps in the formation of $H$. pylori biofilm and the induction of antibiotic tolerance will be presented in the "Efflux pump activity" section.

Apart from the increased level of SpoT, proteomic studies by Wuchta et al. [77] and Loke et al. [78] showed an increase in the production of the following components in spherical H. pylori forms: outer membrane proteins (Omp7 (HopF), Omp8 (HopG), Omp11 (HorE), Omp15 (HopE), and Omp25 (HopI)), transporter proteins/efflux pumps, flagellin $\mathrm{A}$, urease and hydrogenase subunits, proteins regulating the metal ions concentration (e.g., NikR being crucial for urease and hydrogenase activity [79]), CagE and $\mathrm{CagV}$ (stabilizing the T4SS pilus biogenesis [80]), VacA (related to cytotoxicity and immunosuppression induction [81]), lipoprotein LPP20 and TNF- $\alpha$-inducing protein (both contributing to the carcinogenesis promotion [82]), as well as MreB (influencing the action of urease, hydrogenase, and VacA [83]).

Research on the transcriptome/proteome of coccoid H. pylori forms and their influence on biofilm formation is a very difficult task. This is associated with the lack of a uniform procedure stimulating the transition of H. pylori from spiral to coccoid forms. Some reach teams use stressful conditions, such as nutritional starvation [43] or exposure to high oxygen concentrations [84], while others achieve this through a prolonged cultivation $[77,78]$. However, it cannot be denied that such procedures can independently affect the transcriptome and/or proteome of $H$. pylori cells. A review describing the difficulties in laboratory studies on coccoid H. pylori forms was published by Krzyżek and Grande (2020) [71]. Additionally, it is also worth mentioning that spherical H. pylori forms tend to self-aggregate and create biofilms [72,85], so it is difficult to distinguish planktonic and biofilm forms of this bacterium. According to the authors of this review, it seems that the processes of morphological transformation and biofilm formation of $H$. pylori are closely related and may induce one another, as observed in other microorganisms [86-89]. Spherical forms may stimulate biofilm formation through a high autoaggregation capacity, while biofilm may intensify the transition of $H$. pylori to spherical forms through the presence of niches with suboptimal growth conditions (e.g., reduced concentrations of nutrients or respiratory gases). Certainly, research in this area is absolutely necessary to better understand these processes.

\subsection{Metabolic Activity and Matrix Production}

Metabolomic studies on a selected collection of $H$. pylori strains, defined as weak and strong biofilm producers, showed that the former were characterized by a more intense and wider range of produced metabolites than strong biofilm producers [57]. These data are consistent with the observations of Hathroubi et al. [21,22], who showed a significant reduction in the expression of genes related to 
metabolism in biofilm H. pylori forms. Nevertheless, it should be remembered that biofilm forms are still metabolically active, and this activity may influence the composition of biofilm matrix [57].

Using confocal laser scanning microscopy (CLSM) and selective staining of biofilm components, it was found that the H. pylori biofilm matrix consists of proteins, extracellular DNA (eDNA), and sugars [21,24]. However, it was pointed out that proteins seem to be the most important units of the biofilm, because the treatment with proteinase $\mathrm{K}$ at any stage of biofilm development caused its significant degradation. The eDNA was also important (confirmed by the degradative activity of DNase), but only in the early stages of the biofilm formation.

In addition to the above illustrative results showing the components of $H$. pylori biofilm, others focused on the detailed chemical characteristics of this structure $[20,56,90]$. In the first study, it was determined that this polymer consists of various sugars, including fucose, glucose, galactose, $\mathrm{N}$-acetylglucosamine, and N-acetylneuraminic acid, which largely constitute components of LPS and peptidoglycan [20]. Fatty acids were also represented by the compounds derived from $H$. pylori LPS, i.e., tetradecanoic acid $\left(C_{14}\right)$, hexadecanoic acid $\left(C_{16}\right)$, and octadecanoic acid $\left(C_{18}\right)$. Covering amino acids, these were predominated by: asparagine/aspartic acid, glutamine/glutamic acid, glycine, alanine, and leucine. Another study focused on the protein and sugar components of H. pylori biofilm [56]. The main sugar in mature biofilms was mannose (approximately $80 \%$ ), the dominance of which was associated with numerous proteomannans (1,3- and 1,4-mannose bonds). Among proteins, attention was also paid to the importance of neutrophil-activating protein $\mathrm{A}(\mathrm{NapA})$ in biofilm formation ( $\triangle$ napA mutants showed reduced ability to create this structure) [56]. This may be linked with the strongly positive charge of this protein [91], explaining the preference of this bacterium for adhesion to negatively charged surfaces [24]. The last study determined surface-related $H$. pylori sugars, and found that these components mainly include LPS components, mannose-rich glycosides, and $\alpha$-glucans [90]. A correlation was also found between the culture conditions (and thus the type of biofilm) and the sugar composition of the H. pylori cell surface. In strains grown on solid media, an increase in the number of amyloids ( $\alpha-(1,4)$-D-glucan amyloids) and a decrease in the number of LPS-related sugars was observed, while in liquid cultures the relationship was reversed.

All the above results indicate that the chemical components (their composition and quantity) may have a direct impact on the structure and stabilization of H. pylori biofilm. Moreover, many of these compounds are derived from structural organelles of bacterial cells. Thus, in order to better understand the complexity of the biofilm matrix, it is also necessary to take a closer look at the role and function of individual organelles in the physiology of H. pylori.

\subsection{Secretion of Outer Membrane Vesicles}

When considering the extracellular structures of H. pylori, which play an important role in biofilm formation, membrane vesicles should be mentioned. Membrane vesicles are spherical structures with nanometric dimensions that transport a variety of chemicals, delivering them to the target site in an effective concentration and conditioning protection against environmental factors, such as the action of nucleases and peptidases [92-94]. Membrane vesicles are produced in all phases of microbial growth and secreted by both Gram-positive and Gram-negative bacteria, including H. pylori $[95,96]$.

The research group of Grande et al. [97] found that significant amounts of eDNA can be found in $H$. pylori biofilm samples. However, the existence of denoting differences in intracellular and extracellular DNA profiles was determined with the help of random amplified polymorphic DNA (RAPD) analysis, indicating that cell lysis is not the main source of this component in biofilm. Further studies by this team determined that the vast majority of eDNA in H. pylori biofilm is related to OMVs [25]. It was also found that OMVs secreted by biofilm cells were secreted more intensively (approximately $24,800 \mathrm{OMVs} / \mathrm{mL})$, had four times more eDNA, and possessed a more negative charge $(-30 \mathrm{mV})$ than that produced by planktonic cells $(18,000 \mathrm{OMVs} / \mathrm{mL}$ and $-25 \mathrm{mV})[25,98]$. On this basis, the participation of OMVs in genetic variation and scaffolding of biofilm has been suggested $[25,97,98]$. The assistance of these extracellular structures in the formation of $H$. pylori biofilm may play an important 
role in the early stages of this structure formation, which seems to be confirmed by the observations of Windham et al. [24] and Yonezawa et al. [99]. This could be related to the generation of negative surface charge by OMVs, which is preferred for $H$. pylori adhesion [24]. Although this type of mechanism has not yet been confirmed experimentally, the SEM analysis of $H$. pylori cells adhering preferentially to OMVs clusters seem to support the above hypothesis (Figure 5).

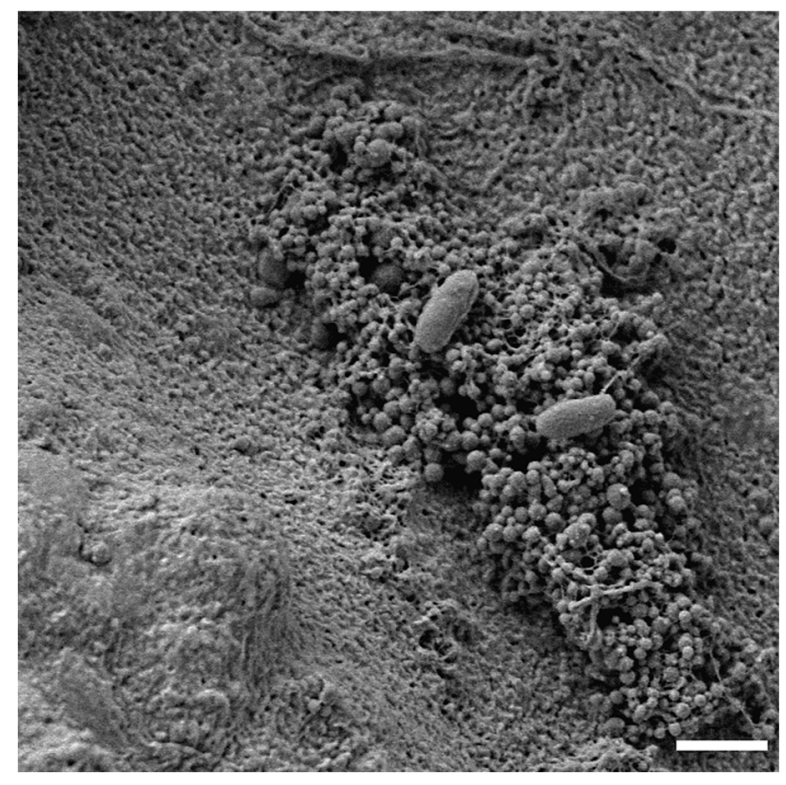

Figure 5. Representative photo of a clinical H. pylori 8064 strain selectively adhering to the surface of a high accumulation of outer membrane vesicles (OMVs). The scale bar shows $2 \mu \mathrm{m}$.

The involvement of OMVs in the formation of $H$. pylori biofilm was also independently investigated by a Japanese team led by Yonezawa et al. [99-101]. During the analysis of eight strains of H. pylori, it was noticed that one of them-H. pylori TK1402-was characterized by several times more intense biofilm production [99]. During microscopic observations, it was noticed that the main component of the matrix were OMVs. Further analysis of this group showed that OMVs from the H. pylori TK1402 strain possessed an outer membrane protein with a specific amino acid sequence $[100,101]$. This protein was Omp21 (also referred to as HopB or AlpB) and the variable region at positions 121-146 was crucial for its adhesive function [101]. In the comparison of H. pylori TK1402 with other strains, it was found that the former expressed alpB faster (24-h culture) than the others ( $48 \mathrm{~h}$ ). Additionally, in H. pylori $\triangle a l p B$ mutants a 10 -fold reduction in biofilm formation capacity was demonstrated. The above data show that the proteins included in OMVs can play an important, eDNA-independent, structural function in H. pylori biofilm.

In proteomic studies of $H$. pylori OMVs, it was determined that the growth phase of this bacterium influences the size, composition, and preferential cargo of these extracellular structures [102,103]. Among 260 proteins found in OMVs, 171 were specific for these structures (not found in bacterial cells) [102]. Proteome of OMVs was represented by outer membrane proteins, efflux transporter/pump proteins, cytotoxic proteins (e.g., VacA and CagA), as well as numerous flagella components and enzymes with various activities, including catalase, urease, carbonic anhydrase, peptidoglycan modification enzymes, and beta-lactamases. It should be pointed out that many of these enzymes play an important role in the environmental adaptation of $H$. pylori and may be involved in the stress tolerance of this bacterium. The contribution of OMVs in the survival of $H$. pylori after exposure to oxidative stress and the action of cathelicidins or antibiotics has been initially confirmed in recent years [104,105], yet little is known about the molecular mechanisms governing these processes.

Regardless of this, the above studies show the importance of OMVs in the formation of H. pylori biofilm and the response to environmental stress through the assistance in the adhesion processes on 
the colonized surface and bacterial cells, participation in genetic recombination, and neutralization of harmful environmental factors.

\subsection{Efflux Pump Activity}

In the context of the protective function of $H$. pylori biofilm components, one cannot fail to mention efflux pumps and the influence of these structures on the antibiotic resistance of this pathogen. Efflux pumps are proteinaceous transporters anchored in the bacterial cell membrane, the amount of which is highly expressed, e.g., under exposure to antimicrobial substances [106]. Their activity is related to the removal of substances harmful to the microbial physiology into the extracellular environment, and therefore, they are currently considered as one of the most important factors determining the antibiotic resistance of microbes. Moreover, the efflux pumps can also participate in the export of factors related to the microbial communication (autoinducers) or substances constituting the building units of matrix, thus playing an important role in the process of biofilm development $[107,108]$.

In many studies on H. pylori biofilms, it was found that cells in the biofilm phase are less susceptible to antibiotics $[23,36-38,53,54,76]$. It was determined that minimal biofilm eradication concentrations (MBECs) were several times higher than minimal bactericidal concentrations (MBCs) or minimal inhibitory concentrations (MICs) recorded for planktonic cells, although in some cases the values were dramatically different. In a study conducted in 2020, on a large pool of clinical H. pylori strains [23], MBECs for amoxicillin were shown to be 1000-fold higher than MICs for planktonic forms $(16 \mu \mathrm{g} / \mathrm{mL}$ vs. $0.016 \mu \mathrm{g} / \mathrm{mL}$ ). Additionally, MBEC values for clarithromycin and tetracycline were 31-fold higher, while for levofloxacin and metronidazole, they were increased by 16 and 8 times, receptively. On the basis of the obtained results, the correlation between MBECs and the biofilm production capacity of $H$. pylori strains (expressed as optical density of crystal violet stained-biofilms) was determined. There was a significant correlation between the biofilm amount and MBECs for amoxicillin, levofloxacin, and clarithromycin. However, no correlation was noticed when determining the MICs of planktonic forms, i.e., values that are classically checked in the laboratory diagnosis of H. pylori resistance. On this basis, the authors of the article postulated the need to verify MBECs in the routine H. pylori antibiotic resistance determination [23].

The efflux pumps play an important role in generating $H$. pylori biofilm resistance. Independent results of various research teams show that biofilm H. pylori cells possess a several-fold increase in the expression of genes encoding the efflux pumps compared to planktonic cells [37-39,53-55,76]. Such an observation was proven for 22 genes of the efflux pumps, including HP0471 (kefB) [38,76], HP0497 [38,76], HP0605 (hefA) [37,53-55], HP0939 (yckJ) [38,76], HP1165 (tetA) [39,54,55], HP1174 $(g \ln P)$ [39,55], HP1327 (crdB/hefG) [37,53], HP1486 (ybhS) [39,55], and HP1489 [37,53]. In addition, it was found that the expression level of the efflux pump genes was higher in clinical, multidrug-resistant H. pylori strains than in susceptible isolates of this bacterium $[38,39,76]$, showing a direct correlation between the production of transporter proteins and the resistance phenotype. It has also been shown that spoT is expressed at a higher level in coccoid H. pylori forms [75], and this gene plays an important role in controlling the biofilm structure and efflux pump activity $[38,39,76]$. Thus, in line with previous reports pointing to the important role of SpoT in the transition to the stationary phase of microbes [109], it is postulated that this protein is involved in the global monitoring of adaptability and response to environmental stress of $H$. pylori, including morphological variability, efflux pumps activity, and biofilm production.

\subsection{Quorum Sensing and a Role of Flagella in Biofilm Formation}

When describing the genes coordinating the transition of microorganisms from the logarithmic growth phase to the stationary phase, one should also mention $l u x S$, a gene involved in the production of AI-2 and microbial communication (the so-called quorum sensing) [110,111].

For H. pylori, it has been shown that the expression of luxS increases in the initial stages of growth, reaches its maximum during the late logarithmic phase (around the second day), and then 
gradually decreases, presenting a minimal level of expression during the stationary phase $[46,58,59,112]$. This was also confirmed by the transcriptomic analysis of biofilm $H$. pylori forms showing a reduction in the expression of $\operatorname{luxS}$ and other genes related to communication with AI-2, i.e., HPG27_227 (aibA; a periplasmic uptake protein AI-2) and HPG27_526 (an exporter of AI-2) [22]. The potential inverse relationship between LuxS production and the transition to the biofilm phase was demonstrated with the use of $\Delta l u x S$ mutants, which revealed several times higher biofilm production compared to the wild strain $[26,40,48]$. The observations of increased biofilm formation in luxS-nonproducing strains were associated with a reduction in the amount of Al-2, which is a stimulus to chemorepulsion (negative chemotaxis), and thus, an enhanced sedentary H. pylori lifestyle [26,48]. These suggestions were indirectly confirmed later when the decreased expression of genes encoding flagella components (including flaA, flgE, fliI, mot $A$, and $\operatorname{mot} B$ ) was noticed in $\triangle l u x S$ mutants [26].

New light was shed on the significance of flagella by Hathroubi et al. [21,22], who showed, during the transcriptomic analysis of planktonic and biofilm H. pylori forms, higher flagella gene expression in the latter group (even seven times higher for some genes). The obtained results were confirmed by this team during the observation of biofilm production in the $\Delta f l i M$ (lack of flagella) and $\triangle m o t B$ (flagella present, but lack of motility) mutants, for which a 25 -fold and 6-fold reduction in the amount of biofilm were shown, respectively [21]. On this basis, it was concluded that flagella is an important structural component of $H$. pylori biofilms [21,22].

The above results show the multitude of interactions taking place during the formation of the microbial biofilm and the difficulties in unambiguously assessing the usefulness or non-usefulness of H. pylori genes during the formation of this complex structure.

\section{Holistic Model Describing the Transition of H. pylori into the Biofilm Phase}

The process of $H$. pylori adhesion to the surface is stimulated by the negative charge of the substrate [24]; hence, the secretion of OMVs with an anchored eDNA (a molecule generating their negative charge) may facilitate the first stages of adhesion $[25,97,98]$. However, it should be remembered that this mechanism is not obligatory, but rather may help to facilitate adhesion. The interaction of OMVs with bacterial cells is conditioned by both the interaction of eDNA with many positively charged H. pylori proteins [113] and also directly by the presence of numerous adhesins incorporated into OMVs $[101,102]$. The processes described above take place in the early stages of biofilm formation (the microcolony formation), which seems to be confirmed by studies suggesting the importance of eDNA in the early but not late stages of $H$. pylori biofilm formation [24].

Further steps in biofilm development appear to be largely controlled by global regulatory proteins $[21,22,39,43,52,112]$. Within them, some are induced during the transition into biofilm phase, including HspR, HrcA, and CrdR, all of which increase the expression of adhesins and flagella [49,66,67]; aconitase stimulates the production of flagella and the activity of urease and hydrogenase [62]; RsfS inhibits metabolic intensity and proteins translation [68]; SpoT supervises the biofilm matrix production and the efflux pumps activity $[39,76]$. Other global regulators, such as ArsS and LuxS, both controlling the mobility and maintaining bacteria in planktonic forms, are inhibited [26,48,52,69].

During the maturation of the microcolony into biofilm, a high number of morphological transformations occur, which ultimately result in the presence of a large population of coccoid forms of this bacterium [70,71]. This morphotype is associated with an increase in the expression of adhesins, urease, and hydrogenase as well as transporter proteins/efflux pumps $[75,77,78]$. In addition, spherical forms intensively secrete OMVs, which additionally stabilize the biofilm structure, but also participate in the process of genetic recombination and tolerance to environmental stress (e.g., by the presence of numerous degradative enzymes) $[25,104,105]$. Efflux pumps, intensively expressed by the coccoid forms of $H$. pylori, take part in matrix production in the process of active ejection of building components into the extracellular environment and protect microbial cells against the bactericidal effect of antimicrobials $[38,39,76]$. Flagella, which are also highly expressed during biofilm formation, may be an independent, additional stabilizer of this structure [21,22]. Numerous protein components 
of $H$. pylori biofilms, including adhesins, flagella, or efflux pumps, are important at all stages of biofilm formation $[21,22,24,36]$. This is confirmed by the results showing the ability of proteinases to significantly degrade the biofilm of this bacterium both in the early and late stages of this structure development [24]. Sugar components are also part of the biofilm matrix and are mainly derived from LPS and peptidoglycan, indicating that the active OMVs secretion, efflux pump activity, and/or cell lysis contribute to the deposition of sugars in this polymer $[20,90]$.

In summary, biofilm formation is a stepwise and highly complex process (Figure 6). A number of changes in the expression and translation of $H$. pylori genes appear to be involved in the transition from planktonic to biofilm phase. Moreover, the process of biofilm structure development is influenced by various environmental factors and these of microbial origin, i.e., virulence and adaptive changes (morphological variability, OMVs secretion, metabolism, and efflux pumps activity).

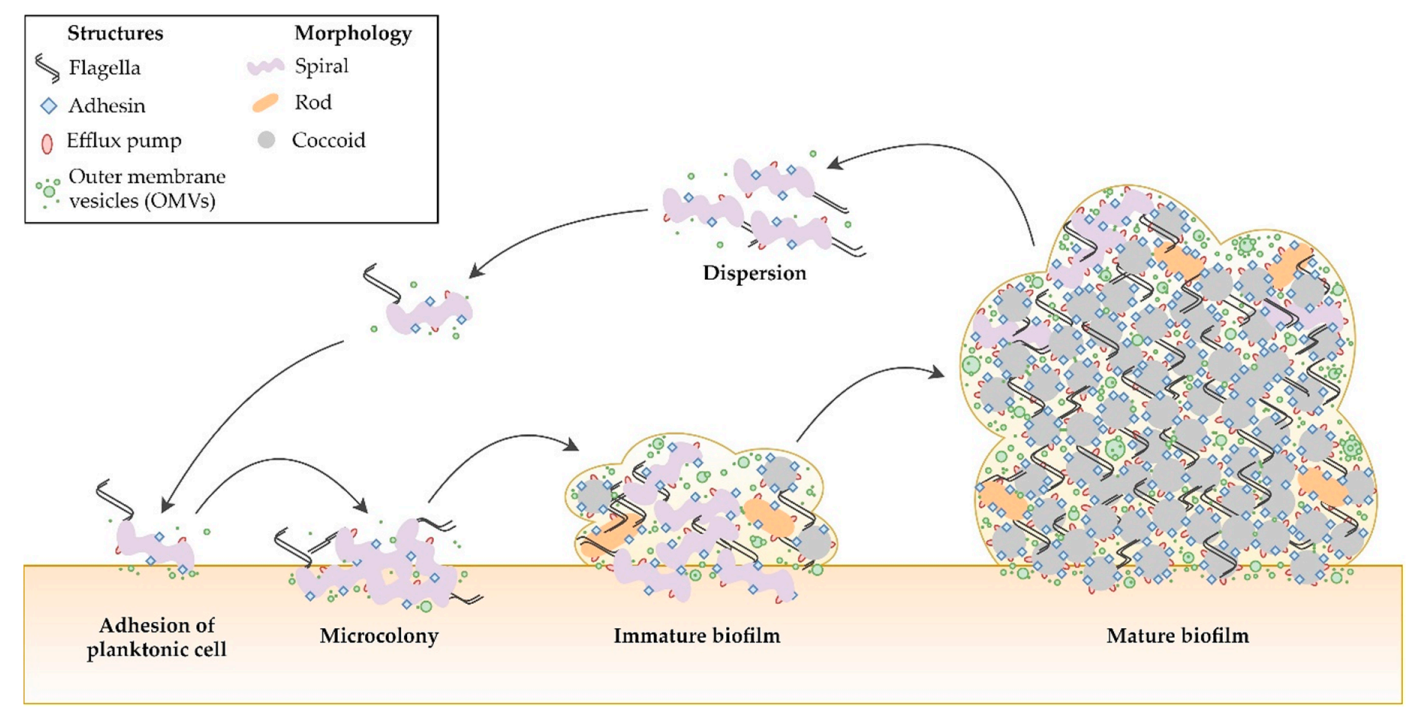

Figure 6. Stages of H. pylori biofilm development. Transition of bacteria from planktonic to biofilm phase is associated with the transformation of spiral forms into coccoids, as well as increased expression of structural components (adhesins, flagella, and efflux pumps) and intensified secretion of outer membrane vesicles (OMVs). All of them determine the stabilization of the H. pylori biofilm structure.

\section{Limitations and Challenges in H. pylori Biofilm Research}

There is no doubt that research of H. pylori biofilm is still in its infancy. Nevertheless, this subject, especially in recent years, has been gaining momentum. Therefore, it is worth paying attention to factors that may inhibit or slow down the speed of this development.

Unquestionably, transcriptomic and proteomic studies have great cognitive value in the analysis of $H$. pylori transition to the biofilm phase, which has been strongly outlined in this review article. It should be emphasized here that their results largely depend on the knowledge about the function of specific genes and proteins. As can be seen quite easily, even in recent 'omics' research on H. pylori, the function of about $1 / 3 \mathrm{rd}$ of the genes or proteins that are defined as being significantly altered in expression is unknown (termed as "hypothetical protein") [21,22,77,78,102]. It seems, therefore, that the substantial amount of future research on $H$. pylori should focus on determining their role in the physiology of this pathogen.

Differences in the medium composition and culture conditions significantly affect the obtained results. This is particularly important in the case of 'omics' techniques, which, because of their high sensitivity, bring out all such differences. At this point, it is worth recalling the previously discussed example of discrepancies in the expression of genes encoding antioxidant proteins [22,43,56], which were most likely the result of the analysis of distinct types of $H$. pylori biofilms. Some groups studied biofilm cells formed as microcolonies or a pellicle at the air-liquid interface (both exposed to oxidative 
stress) [43,56], while others focused on biofilm created as a bacterial sediment (exposure to oxygen was minimal) [22]. In the opinion of the authors of this review article, the standardization of all research procedures is not necessarily needed, because their diversity is a factor resulting in various interesting observations. However, the research procedure and the type of the analyzed bacterial cells should be very precisely indicated each time, so that the subsequent analysis of the results by other research teams is as easy as possible.

Another future challenge is to establish a specific procedure to verify the sensitivity of $H$. pylori biofilms and incorporate it into the routine diagnosis of antibiotic resistance of this bacterium [23]. It is certainly a task that will neither be easy to perform nor achievable in the coming years. However, this challenge is worth to be taken, because more and more studies have indicated the protective role of $H$. pylori biofilm in antibiotic recalcitrance, especially in the course of therapeutically difficult, recurrent cases of infections caused by this microorganism. In contrast to the previous paragraph, here, the authors of the review strongly encourage the establishment of a single, well-defined procedure allowing the comparison of minimum inhibitory or bactericidal values of $H$. pylori biofilms between different research teams/diagnostic laboratories.

\section{Conclusions}

The process of transition of H. pylori from planktonic into biofilm phase is a stepwise and highly complex process. The most important features describing this process are:

1. Strong influence of virulence and adaptive responses (morphological transformation, membrane vesicles secretion, matrix production, efflux pump activity, and intermicrobial communication) on biofilm development and its structure.

2. Higher expression of adhesins, lipopolysaccharide, flagella, components of T4SS systems, toxin-antitoxin systems, efflux pumps, enzymes regulating $\mathrm{pH}$ (e.g., urease) and responsible for obtaining alternative energy sources (e.g., hydrogenase), and proteins related to the cell wall rearrangement.

3. Lower expression of factors involved in metabolism, translation, and quorum sensing related to the autoinducer-2 (AI-2) activity.

Author Contributions: Conceptualization, P.K.; formal analysis, P.K.; obtaining of scanning electron microscopy photos, P.M.; writing - original draft preparation, P.K. and R.G.; writing-review and editing, P.K., E.P., R.G., and G.G.; visualization, P.K.; supervision, G.G.; funding acquisition, P.K. and G.G. All authors have read and agreed to the published version of the manuscript.

Funding: The study was supported by the Wroclaw Medical University grant No: STM.A130.20.002. The funders had no role in the study design, data collection, and analysis, decision to publish, or preparation of the manuscript. The publication was prepared under the project financed from the funds granted by the Ministry of Science and Higher Education in the "Regional Initiative of Excellence" program for the years 2019-2022, project number 016/RID/2018/19, the amount of funding was 11,998,121.30 PLN.

Conflicts of Interest: The authors declare no conflict of interest.

\section{References}

1. Langenheder, S.; Bulling, M.T.; Solan, M.; Prosser, J.I. Bacterial Biodiversity-Ecosystem Functioning Relations are Modified by Environmental Complexity. PLoS ONE 2010, 5, e10834. [CrossRef]

2. Høiby, N.; Bjarnsholt, T.; Moser, C.; Bassi, G.L.; Coenye, T.; Donelli, G.; Hall-Stoodley, L.; Holá, V.; Imbert, C.; Kirketerp-Møller, K.; et al. ESCMID* Guideline for the Diagnosis and Treatment of Biofilm Infections 2014. Clin. Microbiol. Infect. 2015, 21, S1-S25. [CrossRef]

3. Flemming, H.C.; Wingender, J.; Szewzyk, U.; Steinberg, P.; Rice, S.A.; Kjelleberg, S. Biofilms: An Emergent Form of Bacterial Life. Nat. Rev. Microbiol. 2016, 14, 563-575. [CrossRef]

4. Lebeaux, D.; Ghigo, J.-M.; Beloin, C. Biofilm-Related Infections: Bridging the Gap between Clinical Management and Fundamental Aspects of Recalcitrance toward Antibiotics. Microbiol. Mol. Biol. Rev. 2014, 78, 510-543. [CrossRef] 
5. Vestby, L.K.; Grønseth, T.; Simm, R.; Nesse, L.L. Bacterial Biofilm and its Role in the Pathogenesis of Disease. Antibiotics 2020, 9, 59. [CrossRef]

6. Paluch, E.; Rewak-Soroczyńska, J.; Jęrusik, I.; Mazurkiewicz, E.; Jermakow, K. Prevention of Biofilm Formation by Quorum Quenching. Appl. Microbiol. Biotechnol. 2020, 104, 1871-1881. [CrossRef]

7. Høiby, N. A Short History of Microbial Biofilms and Biofilm Infections. APMIS 2017, 125, 272-275. [CrossRef]

8. Ciofu, O.; Rojo-Molinero, E.; Macià, M.D.; Oliver, A. Antibiotic Treatment of Biofilm Infections. APMIS 2017, 125, 304-319. [CrossRef]

9. Toh, J.W.T.; Wilson, R.B. Pathways of Gastric Carcinogenesis, Helicobacter pylori Virulence and Interactions with Antioxidant Systems, Vitamin C and Phytochemicals. Int. J. Mol. Sci. 2020, 21, 6451. [CrossRef]

10. Alipour, M. Molecular Mechanism of Helicobacter pylori-Induced Gastric Cancer. J. Gastrointest. Cancer 2020, 14, 1-8. [CrossRef]

11. Rhee, K.H.; Park, J.S.; Cho, M.J. Helicobacter pylori: Bacterial Strategy for Incipient Stage and Persistent Colonization in Human Gastric Niches. Yonsei Med. J. 2014, 55, 1453-1466. [CrossRef] [PubMed]

12. Denic, M.; Touati, E.; De Reuse, H. Review: Pathogenesis of Helicobacter pylori Infection. Helicobacter 2020, 25, e12736. [CrossRef]

13. Yamaoka, Y.; Graham, D.Y. Helicobacter pylori Virulence and Cancer Pathogenesis. Futur. Oncol. 2014, 10, 1487-1500. [CrossRef]

14. Schulz, C.; Kupčinskas, J. Review-Helicobacter pylori and Non-Malignant Upper Gastro-Intestinal Diseases. Helicobacter 2020, 25, e12738. [CrossRef]

15. Robinson, K. Helicobacter pylori-Mediated Protection against Extra-Gastric Immune and Inflammatory Disorders: The Evidence and Controversies. Diseases 2015, 3, 34-55. [CrossRef] [PubMed]

16. Pellicano, R.; Ianiro, G.; Fagoonee, S.; Settanni, C.R.; Gasbarrini, A. Review: Extragastric Diseases and Helicobacter pylori. Helicobacter 2020, 25, e12741.

17. Yu, Y.; Zhu, S.; Li, P.; Min, L.; Zhang, S. Helicobacter pylori Infection and Inflammatory Bowel Disease: A Crosstalk between Upper and Lower Digestive Tract. Cell Death Dis. 2018, 9, 961. [CrossRef]

18. Ansari, S.; Yamaoka, Y. Helicobacter pylori Virulence Factors Exploiting Gastric Colonization and Its Pathogenicity. Toxins 2019, 11, 677. [CrossRef]

19. Percival, S.L.; Suleman, L. Biofilms and Helicobacter pylori: Dissemination and Persistence within the Environment and Host. World J. Gastrointest. Pathophysiol. 2014, 5, 122-132.

20. Stark, R.M.; Gerwig, G.J.; Pitman, R.S.; Potts, L.F.; Williams, N.A.; Greenman, J.; Weinzweig, I.P.; Hirst, T.R.; Millar, M.R. Biofilm Formation by Helicobacter pylori. Lett. Appl. Microbiol. 1999, 28, 121-126. [CrossRef]

21. Hathroubi, S.; Zerebinski, J.; Ottemann, K.M. Helicobacter pylori Biofilm Involves a Multigene Stress-Biased Response, Including a Structural Role for Flagella. mBio 2018, 9, e01973-18. [CrossRef]

22. Hathroubi, S.; Zerebinski, J.; Ottemann, K.M. Helicobacter pylori Biofilm Cells are Metabolically Distinct, Express Flagella, and Antibiotic Tolerant. bioRxiv 2019. [CrossRef]

23. Fauzia, K.A.; Miftahussurur, M.; Syam, A.F.; Waskito, L.A.; Doohan, D.; Rezkitha, Y.A.A.; Matsumoto, T.; Tuan, V.P.; Akada, J.; Yonezawa, H.; et al. Biofilm Formation and Antibiotic Resistance Phenotype of Helicobacter pylori Clinical Isolates. Toxins 2020, 12, 473. [CrossRef]

24. Windham, I.H.; Servetas, S.L.; Whitmire, J.M.; Pletzer, D.; Hancock, R.E.W.; Merrell, D.S. Helicobacter pylori Biofilm Formation Is Differentially Affected by Common Culture Conditions, and Proteins Play a Central Role in the Biofilm Matrix. Appl. Environ. Microbiol. 2018, 84, e00391-18.

25. Grande, R.; Di Marcantonio, M.C.; Robuffo, I.; Pompilio, A.; Celia, C.; Di Marzio, L.; Paolino, D.; Codagnone, M.; Muraro, R.; Stoodley, P.; et al. Helicobacter pylori ATCC 43629/NCTC 11639 Outer Membrane Vesicles (OMVs) from Biofilm and Planktonic Phase Associated with Extracellular DNA (eDNA). Front. Microbiol. 2015, 6, 1369. [CrossRef]

26. Anderson, J.K.; Huang, J.Y.; Wreden, C.; Sweeney, E.G.; Goers, J.; Remington, S.J.; Guillemin, K. Chemorepulsion from the Quorum Signal Autoinducer-2 Promotes Helicobacter pylori Biofilm Dispersal. mBio 2015, 6, e00379. [CrossRef]

27. Tan, S.; Tompkins, L.S.; Amieva, M.R. Helicobacter pylori Usurps Cell Polarity to Turn the Cell Surface into a Replicative Niche. PLoS Pathog. 2009, 5, e1000407. [CrossRef] [PubMed]

28. Attaran, B.; Falsafi, T.; Moghaddam, A.N. Study of Biofilm Formation in C57Bl/6J Mice by Clinical Isolates of Helicobacter pylori. Saudi J. Gastroenterol. 2016, 22, 161-168. 
29. Carron, M.A.; Tran, V.R.; Sugawa, C.; Coticchia, J.M. Identification of Helicobacter pylori Biofilms in Human Gastric Mucosa. J. Gastrointest. Surg. 2006, 10, 712-717. [CrossRef]

30. Coticchia, J.M.; Sugawa, C.; Tran, V.R.; Gurrola, J.; Kowalski, E.; Carron, M.A. Presence and Density of Helicobacter pylori Biofilms in Human Gastric Mucosa in Patients With Peptic Ulcer Disease. J. Gastrointest. Surg. 2006, 10, 883-889. [CrossRef]

31. Ng, C.G.; Loke, M.F.; Goh, K.L.; Vadivelu, J.; Ho, B. Biofilm Formation Enhances Helicobacter pylori Survivability in Vegetables. Food Microbiol. 2017, 62, 68-76. [CrossRef]

32. Linke, S.; Lenz, J.; Gemein, S.; Exner, M.; Gebel, J. Detection of Helicobacter pylori in Biofilms by Real-Time PCR. Int. J. Hyg. Environ. Health 2010, 213, 176-182. [CrossRef] [PubMed]

33. Park, S.R.; Mackay, W.G.; Reid, D.C. Helicobacter sp. Recovered from Drinking Water Biofilm Sampled from a Water Distribution System. Water Res. 2001, 35, 1624-1626. [CrossRef]

34. Bunn, J.E.G.; MacKay, W.G.; Thomas, J.E.; Reid, D.C.; Weaver, L.T. Detection of Helicobacter pylori DNA in Drinking Water Biofilms: Implications for Transmission in Early Life. Lett. Appl. Microbiol. 2002, 34, 450-454. [CrossRef] [PubMed]

35. Percival, S.L.; Thomas, J.G. Transmission of Helicobacter pylori and the Role of Water and Biofilms. J. Water Health 2009, 7, 469-477. [CrossRef] [PubMed]

36. Hathroubi, S.; Zerebinski, J.; Clarke, A.; Ottemann, K.M. Helicobacter pylori Biofilm Confers Antibiotic Tolerance in Part via a Protein-Dependent Mechanism. Antibiotics 2020, 9, 355. [CrossRef]

37. Yonezawa, H.; Osaki, T.; Hojo, F.; Kamiya, S. Effect of Helicobacter pylori Biofilm Formation on Susceptibility to Amoxicillin, Metronidazole and Clarithromycin. Microb. Pathog. 2019, 132, 100-108. [CrossRef]

38. Cai, Y.; Wang, C.; Chen, Z.; Xu, Z.; Li, H.; Li, W.; Sun, Y. Transporters HP0939, HP0497, and HP0471 Participate in Intrinsic Multidrug Resistance and Biofilm Formation in Helicobacter pylori by Enhancing Drug Efflux. Helicobacter 2020, 25, e12715. [CrossRef]

39. Ge, X.; Cai, Y.; Chen, Z.; Gao, S.; Geng, X.; Li, Y.; Li, Y.; Jia, J.; Sun, Y. Bifunctional Enzyme SpoT Is Involved in Biofilm Formation of Helicobacter pylori with Multidrug Resistance by Upregulating Efflux Pump Hp1174 (gluP). Antimicrob. Agents Chemother. 2018, 62, e00957-18. [CrossRef]

40. Cole, S.P.; Harwood, J.; Lee, R.; She, R.; Guiney, D.G. Characterization of Monospecies Biofilm Formation by Helicobacter pylori. J. Bacteriol. 2004, 186, 3124-3132. [CrossRef]

41. Servetas, S.L.; Carpenter, B.M.; Haley, K.P.; Gilbreath, J.J.; Gaddy, J.A.; Scott Merrell, D. Characterization of Key Helicobacter pylori Regulators Identifies a Role for ArsRS in Biofilm Formation. J. Bacteriol. 2016, 198, 2536-2548. [CrossRef] [PubMed]

42. Ratthawongjirakul, P.; Thongkerd, V.; Chaicumpa, W. The Impacts of a fliD Mutation on the Biofilm Formation of Helicobacter pylori. Asian Pac. J. Trop. Biomed. 2016, 6, 1008-1014. [CrossRef]

43. Shao, C.; Sun, Y.; Wang, N.; Yu, H.; Zhou, Y.; Chen, C.; Jia, J. Changes of Proteome Components of Helicobacter pylori Biofilms Induced by Serum Starvation. Mol. Med. Rep. 2013, 8, 1761-1766. [CrossRef]

44. Krzyżek, P.; Gościniak, G.; Fijałkowski, K.; Migdał, P.; Dziadas, M.; Owczarek, A.; Czajkowska, J.; Aniołek, O.; Junka, A. Potential of Bacterial Cellulose Chemisorbed with Anti-Metabolites, 3-Bromopyruvate or Sertraline, to Fight against Helicobacter pylori Lawn Biofilm. Int. J. Mol. Sci. 2020, 21, 9507. [CrossRef]

45. Azevedo, N.F.; Pinto, A.R.; Reis, N.M.; Vieira, M.J.; Keevil, C.W. Shear Stress, Temperature, and Inoculation Concentration Influence the Adhesion of Water-Stressed Helicobacter pylori to Stainless Steel 304 and Polypropylene. Appl. Environ. Microbiol. 2006, 72, 2936-2941. [CrossRef]

46. Bessa, L.J.; Grande, R.; DI Iorio, D.; DI Giulio, M.; DI Campli, E.; Cellini, L. Helicobacter pylori Free-Living and Biofilm Modes of Growth: Behavior in Response to Different Culture Media. APMIS 2013, 121, 549-560. [CrossRef]

47. Cárdenas-Mondragón, M.G.; Ares, M.A.; Panunzi, L.G.; Pacheco, S.; Camorlinga-Ponce, M.; Girón, J.A.; Torres, J.; De la Cruz, M.A. Transcriptional Profiling of Type II Toxin-Antitoxin Genes of Helicobacter pylori under Different Environmental Conditions: Identification of HP0967-HP0968 System. Front. Microbiol. 2016, 7, 1872. [CrossRef]

48. Sweeney, E.G.; Nishida, A.; Weston, A.; Bañuelos, M.S.; Potter, K.; Conery, J.; Guillemin, K. Agent-Based Modeling Demonstrates How Local Chemotactic Behavior Can Shape Biofilm Architecture. mSphere 2019, 4, e00285-19. [CrossRef] 
49. Hung, C.L.; Cheng, H.H.; Hsieh, W.C.; Tsai, Z.T.Y.; Tsai, H.K.; Chu, C.H.; Hsieh, W.P.; Chen, Y.F.; Tsou, Y.; Lai, C.H.; et al. The CrdRS Two-Component System in Helicobacter pylori Responds to Nitrosative Stress. Mol. Microbiol. 2015, 97, 1128-1141. [CrossRef]

50. De la Cruz, M.A.; Ares, M.A.; von Bargen, K.; Panunzi, L.G.; Martínez-Cruz, J.; Valdez-Salazar, H.A.; Jiménez-Galicia, C.; Torres, J. Gene Expression Profiling of Transcription Factors of Helicobacter pylori under Different Environmental Conditions. Front. Microbiol. 2017, 8, 615. [CrossRef]

51. Wong, E.H.J.; Ng, C.G.; Chua, E.G.; Tay, A.C.Y.; Peters, F.; Marshall, B.J.; Ho, B.; Goh, K.L.; Vadivelu, J.; Loke, M.F. Comparative Genomics Revealed Multiple Helicobacter pylori Genes Associated with Biofilm Formation In Vitro. PLoS ONE 2016, 11, e0166835. [CrossRef] [PubMed]

52. Servetas, S.L.; Doster, R.S.; Kim, A.; Windham, I.H.; Cha, J.H.; Gaddy, J.A.; Merrell, D.S. ArsRS-Dependent Regulation of homB Contributes to Helicobacter pylori Biofilm Formation. Front. Microbiol. 2018, 9, 1497. [CrossRef] [PubMed]

53. Yonezawa, H.; Osaki, T.; Hanawa, T.; Kurata, S.; Ochiai, K.; Kamiya, S. Impact of Helicobacter pylori Biofilm Formation on Clarithromycin Susceptibility and Generation of Resistance Mutations. PLoS ONE 2013, 8, e73301. [CrossRef] [PubMed]

54. Attaran, B.; Falsafi, T.; Ghorbanmehr, N. Effect of Biofilm Formation by Clinical Isolates of Helicobacter pylori on the Efflux-Mediated Resistance to Commonly Used Antibiotics. World J. Gastroenterol. 2017, 23, 1163-1170. [CrossRef] [PubMed]

55. Kazakos, E.I.; Dorrell, N.; Polyzos, S.A.; Deretzi, G.; Kountouras, J. Comment on "Effect of Biofilm Formation by Clinical Isolates of Helicobacter pylori on the Efflux-Mediated Resistance to Commonly Used Antibiotics. " World J. Gastroenterol. 2017, 23, 6194-6196. [CrossRef]

56. Yang, F.L.; Hassanbhai, A.M.; Chen, H.Y.; Huang, Z.Y.; Lin, T.L.; Wu, S.H.; Ho, B. Proteomannans in Biofilm of Helicobacter pylori ATCC 43504. Helicobacter 2011, 16, 89-98. [CrossRef]

57. Wong, E.H.J.; Ng, C.G.; Goh, K.L.; Vadivelu, J.; Ho, B.; Loke, M.F. Metabolomic Analysis of Low and High Biofilm-Forming Helicobacter pylori Strains. Sci. Rep. 2018, 8, 1409. [CrossRef]

58. Cellini, L.; Grande, R.; Traini, T.; Di Campli, E.; Di Bartolomeo, S.; Di Iorio, D.; Caputi, S. Biofilm Formation and Modulation of luxS and rpoD Expression by Helicobacter pylori. Biofilms 2005, 2, 119-127. [CrossRef]

59. Cellini, L.; Grande, R.; Di Campli, E.; Di Bartolomeo, S.; Di Giulio, M.; Traini, T.; Trubiani, O. Characterization of an Helicobacter pylori Environmental Strain. J. Appl. Microbiol. 2008, 105, 761-769. [CrossRef]

60. Bervoets, I.; Charlier, D. Diversity, Versatility and Complexity of Bacterial Gene Regulation Mechanisms: Opportunities and Drawbacks for Applications in Synthetic Biology. FEMS Microbiol. Rev. 2019, 43, 304-339. [CrossRef]

61. Balleza, E.; López-Bojorquez, L.N.; Martínez-Antonio, A.; Resendis-Antonio, O.; Lozada-Chávez, I.; Balderas-Martínez, Y.I.; Encarnación, S.; Collado-Vides, J. Regulation by Transcription Factors in Bacteria: Beyond Description. FEMS Microbiol. Rev. 2009, 33, 133-151. [CrossRef] [PubMed]

62. Austin, C.M.; Wang, G.; Maier, R.J. Aconitase Functions as a Pleiotropic Posttranscriptional Regulator in Helicobacter pylori. J. Bacteriol. 2015, 197, 3076-3086. [CrossRef]

63. Wang, G.; Romero-Gallo, J.; Benoit, S.L.; Blanca Piazuelo, M.; Dominguez, R.L.; Morgan, D.R.; Peek, R.M.; Maier, R.J. Hydrogen Metabolism in Helicobacter pylori Plays a Role in Gastric Carcinogenesis through Facilitating CagA Translocation. mBio 2016, 7, e01022-16. [CrossRef]

64. Kuhns, L.G.; Benoit, S.L.; Bayyareddy, K.; Johnson, D.; Orlando, R.; Evans, A.L.; Waldrop, G.L.; Maier, R.J. Carbon Fixation Driven by Molecular Hydrogen Results in Chemolithoautotrophically Enhanced Growth of Helicobacter pylori. J. Bacteriol. 2016, 198, 1423-1428. [CrossRef] [PubMed]

65. Krüger, N.J.; Knüver, M.T.; Zawilak-Pawlik, A.; Appel, B.; Stingl, K. Genetic Diversity as Consequence of a Microaerobic and Neutrophilic Lifestyle. PLoS Pathog. 2016, 12, e1005626. [CrossRef] [PubMed]

66. Roncarati, D.; Danielli, A.; Spohn, G.; Delany, I.; Scarlato, V. Transcriptional Regulation of Stress Response and Motility Functions in Helicobacter pylori is Mediated by HspR and HrcA. J. Bacteriol. 2007, 189, 7234-7243. [CrossRef] [PubMed]

67. Roncarati, D.; Pinatel, E.; Fiore, E.; Peano, C.; Loibman, S.; Scarlato, V. Helicobacter pylori Stress-Response: Definition of the HrcA Regulon. Microorganisms 2019, 7, 436. [CrossRef] [PubMed]

68. Häuser, R.; Pech, M.; Kijek, J.; Yamamoto, H.; Titz, B.; Naeve, F.; Tovchigrechko, A.; Yamamoto, K.; Szaflarski, W.; Takeuchi, N.; et al. RsFA (YbeB) Proteins are Conserved Ribosomal Silencing Factors. PLoS Genet. 2012, 8, e1002815. [CrossRef] 
69. Acio-Pizzarello, C.R.; Acio, A.A.; Choi, E.J.; Bond, K.; Kim, J.; Kenan, A.C.; Chen, J.; Forsyth, M.H. Determinants of the Regulation of Helicobacter pylori Adhesins Include Repeat Sequences in both Promoter and Coding Regions as Well as the Two-Component System ArsRS. J. Med. Microbiol. 2017, 66, 798-807. [CrossRef]

70. Krzyżek, P.; Gościniak, G. Morphology of Helicobacter pylori as a Result of Peptidoglycan and Cytoskeleton Rearrangements. Prz. Gastroenterol. 2018, 13, 182-195. [CrossRef]

71. Krzyżek, P.; Grande, R. Transformation of Helicobacter pylori into Coccoid Forms as a Challenge for Research Determining Activity of Antimicrobial Substances. Pathogens 2020, 9, 184. [CrossRef] [PubMed]

72. Krzyżek, P.; Biernat, M.M.; Gościniak, G. Intensive Formation of Coccoid Forms as a Feature Strongly Associated with Highly Pathogenic Helicobacter pylori Strains. Folia Microbiol. 2019, 64, 273-281. [CrossRef] [PubMed]

73. Dong, K.; Pan, H.; Yang, D.; Rao, L.; Zhao, L.; Wang, Y.; Liao, X. Induction, Detection, Formation, and Resuscitation of Viable but Non-Culturable State Microorganisms. Compr. Rev. Food Sci. Food Saf. 2020, 19, 149-183. [CrossRef] [PubMed]

74. Kadkhodaei, S.; Siavoshi, F.; Akbari Noghabi, K. Mucoid and Coccoid Helicobacter pylori with Fast Growth and Antibiotic Resistance. Helicobacter 2019, 25, e12678. [CrossRef]

75. Poursina, F.; Fagri, J.; Mirzaei, N.; Safaei, H.G. Overexpression of spoT Gene in Coccoid Forms of Clinical Helicobacter pylori Isolates. Folia Microbiol. 2018, 63, 459-465. [CrossRef]

76. Geng, X.; Li, W.; Chen, Z.; Gao, S.; Hong, W.; Ge, X.; Hou, G.; Hu, Z.; Zhou, Y.; Zeng, B.; et al. The Bifunctional Enzyme SpoT Is Involved in the Clarithromycin Tolerance of Helicobacter pylori by Upregulating the Transporters HP0939, HP1017, HP0497, and HP0471. Antimicrob. Agents Chemother. 2017, 61, e02011-16. [CrossRef]

77. Wuchty, S.; Müller, S.A.; Caufield, J.H.; Häuser, R.; Aloy, P.; Kalkhof, S.; Uetz, P. Proteome Data Improves Protein Function Prediction in the Interactome of Helicobacter pylori. Mol. Cell. Proteom. 2018, 17, 961-973. [CrossRef]

78. Loke, M.F.; Ng, C.G.; Vilashni, Y.; Lim, J.; Ho, B. Understanding the Dimorphic Lifestyles of Human Gastric Pathogen Helicobacter pylori Using the SWATH-Based Proteomics Approach. Sci. Rep. 2016, 6, 26784. [CrossRef]

79. Benoit, S.L.; Seshadri, S.; Lamichhane-Khadka, R.; Maier, R.J. Helicobacter hepaticus NikR Controls Urease and Hydrogenase Activities via the NikABDE and HH0418 Putative Nickel Import Proteins. Microbiology 2013, 159, 136-146. [CrossRef]

80. Shariq, M.; Kumar, N.; Kumari, R.; Kumar, A.; Subbarao, N.; Mukhopadhyay, G. Biochemical Analysis of CagE: A VirB4 Homologue of Helicobacter pylori Cag-T4SS. PLoS ONE 2015, 10, e0142606. [CrossRef]

81. Terebiznik, M.R.; Vazquez, C.L.; Torbicki, K.; Banks, D.; Wang, T.; Hong, W.; Blanke, S.R.; Colombo, M.I.; Jones, N.L. Helicobacter pylori VacA toxin promotes bacterial intracellular survival in gastric epithelial cells. Infect. Immun. 2006, 74, 6599-6614. [CrossRef] [PubMed]

82. Vallese, F.; Mishra, N.M.; Pagliari, M.; Berto, P.; Codolo, G.; de Bernard, M.; Zanotti, G. Helicobacter pylori Antigenic Lpp20 is a Structural Homologue of Tip $\alpha$ and Promotes Epithelial-Mesenchymal Transition. Biochim. Biophys. Acta Gen. Subj. 2017, 1861, 3263-3271. [CrossRef] [PubMed]

83. Zepeda Gurrola, R.C.; Fu, Y.; Rodríguez Luna, I.C.; Benítez Cardoza, C.G.; de Jesús López López, M.; López Vidal, Y.; Gutíerrez, G.R.A.; Rodríguez Pérez, M.A.; Guo, X. Novel protein interactions with an actin homolog (MreB) of Helicobacter pylori determined by bacterial two-hybrid system. Microbiol. Res. 2017, 201, $39-45$. [CrossRef] [PubMed]

84. Zeng, H.; Guo, G.; Mao, X.H.; De Tong, W.; Zou, Q.M. Proteomic Insights into Helicobacter pylori Coccoid Forms under Oxidative Stress. Curr. Microbiol. 2008, 57, 281-286. [CrossRef]

85. Attaran, B.; Falsafi, T. Identification of Factors Associated with Biofilm Formation Ability in the Clinical Isolates of Helicobacter pylori. Iran. J. Biotechnol. 2017, 15, 58-66. [CrossRef]

86. Smith, W.P.J.; Davit, Y.; Osborne, J.M.; Kim, W.D.; Foster, K.R.; Pitt-Francis, J.M. Cell Morphology Drives Spatial Patterning in Microbial Communities. Proc. Natl. Acad. Sci. USA 2017, 114, E280-E286. [CrossRef]

87. Serra, D.O.; Richter, A.M.; Klauck, G.; Mika, F.; Hengge, R. Microanatomy at Cellular Resolution and Spatial Order of Physiological Differentiation in a Bacterial Biofilm. mBio 2013, 4, 103-116. [CrossRef]

88. Bastian, F.O.; Elzer, P.H.; Wu, X. Spiroplasma spp. Biofilm Formation Is Instrumental for Their Role in the Pathogenesis of Plant, Insect and Animal Diseases. Exp. Mol. Pathol. 2012, 93, 116-128. [CrossRef] 
89. Peschek, N.; Herzog, R.; Singh, P.K.; Sprenger, M.; Meyer, F.; Fröhlich, K.S.; Schröger, L.; Bramkamp, M.; Drescher, K.; Papenfort, K. RNA-Mediated Control of Cell Shape Modulates Antibiotic Resistance in Vibrio cholerae. Nat. Commun. 2020, 11, 6067. [CrossRef]

90. Ferreira, J.A.; Pires, C.; Paulo, M.; Azevedo, N.F.; Domingues, M.R.; Vieira, M.J.; Monteiro, M.A.; Coimbra, M.A. Bioaccumulation of Amylose-Like Glycans by Helicobacter pylori. Helicobacter 2009, 14, 559-570. [CrossRef]

91. Fu, H.W. Helicobacter pylori Neutrophil-Activating Protein: From Molecular Pathogenesis to Clinical Applications. World J. Gastroenterol. 2014, 20, 5294-5301. [CrossRef] [PubMed]

92. Schwechheimer, C.; Kuehn, M.J. Outer-Membrane Vesicles from Gram-Negative Bacteria: Biogenesis and Functions. Nat. Rev. Microbiol. 2015, 13, 619. [CrossRef] [PubMed]

93. Jan, A.T. Outer Membrane Vesicles (OMVs) of Gram-negative Bacteria: A Perspective Update. Front. Microbiol. 2017, 8, 1053. [CrossRef] [PubMed]

94. Nagakubo, T.; Nomura, N.; Toyofuku, M. Cracking Open Bacterial Membrane Vesicles. Front. Microbiol. 2020, 10, 3026. [CrossRef]

95. Krzyżek, P. Sekrecja Pęcherzyków Błonowych Jako Mechanizm Promujący Infekcje H. pylori. Postępy Mikrobiol. 2017, 56, 316-325. [CrossRef]

96. Jarzab, M.; Posselt, G.; Meisner-Kober, N.; Wessler, S. Helicobacter pylori-Derived Outer Membrane Vesicles (OMVs): Role in Bacterial Pathogenesis? Microorganisms 2020, 8, 1328. [CrossRef]

97. Grande, R.; Di Giulio, M.; Bessa, L.J.; Di Campli, E.; Baffoni, M.; Guarnieri, S.; Cellini, L. Extracellular DNA in Helicobacter pylori Biofilm: A Backstairs Rumour. J. Appl. Microbiol. 2011, 110, 490-498.

98. Puca, V.; Ercolino, E.; Celia, C.; Bologna, G.; Di Marzio, L.; Mincione, G.; Marchisio, M.; Miscia, S.; Muraro, R.; Lanuti, P.; et al. Detection and Quantification of eDNA-Associated Bacterial Membrane Vesicles by Flow Cytometry. Int. J. Mol. Sci. 2019, 20, 5307. [CrossRef]

99. Yonezawa, H.; Osaki, T.; Kurata, S.; Fukuda, M.; Kawakami, H.; Ochiai, K.; Hanawa, T.; Kamiya, S. Outer Membrane Vesicles of Helicobacter pylori TK1402 are Involved in Biofilm Formation. BMC Microbiol. 2009, 9, 197. [CrossRef]

100. Yonezawa, H.; Osaki, T.; Woo, T.; Kurata, S.; Zaman, C.; Hojo, F.; Hanawa, T.; Kato, S.; Kamiya, S. Analysis of Outer Membrane Vesicle Protein Involved in Biofilm Formation of Helicobacter pylori. Anaerobe 2011, 17, 390. [CrossRef]

101. Yonezawa, H.; Osaki, T.; Fukutomi, T.; Hanawa, T.; Kurata, S.; Zaman, C.; Hojo, F.; Kamiya, S. Diversification of the AlpB Outer Membrane Protein of Helicobacter pylori Affects Biofilm Formation and Cellular Adhesion. J. Bacteriol. 2017, 199, e00729-16. [CrossRef] [PubMed]

102. Zavan, L.; Bitto, N.J.; Johnston, E.L.; Greening, D.W.; Kaparakis-Liaskos, M. Helicobacter pylori Growth Stage Determines the Size, Protein Composition, and Preferential Cargo Packaging of Outer Membrane Vesicles. Proteomics 2019, 19, e1800209. [CrossRef] [PubMed]

103. Turner, L.; Bitto, N.J.; Steer, D.L.; Lo, C.; D'Costa, K.; Ramm, G.; Shambrook, M.; Hill, A.F.; Ferrero, R.L.; Kaparakis-Liaskos, M. Helicobacter pylori Outer Membrane Vesicle Size Determines their Mechanisms of Host Cell Entry and Protein Content. Front. Immunol. 2018, 9, 1466. [CrossRef] [PubMed]

104. Lekmeechai, S.; Su, Y.-C.; Brant, M.; Alvarado-Kristensson, M.; Vallström, A.; Obi, I.; Arnqvist, A.; Riesbeck, K. Helicobacter pylori Outer Membrane Vesicles Protect the Pathogen from Reactive Oxygen Species of the Respiratory Burst. Front. Microbiol. 2018, 9, 1837. [CrossRef] [PubMed]

105. Murray, B.O.; Dawson, R.A.; Alsharaf, L.M.; Winter, J.A. Protective Effects of Helicobacter pylori Membrane Vesicles against Stress and Antimicrobial Agents. Microbiology 2020, 166, 751-758. [CrossRef]

106. Blanco, P.; Hernando-Amado, S.; Reales-Calderon, J.; Corona, F.; Lira, F.; Alcalde-Rico, M.; Bernardini, A.; Sanchez, M.; Martinez, J. Bacterial multidrug efflux pumps: Much more than antibiotic resistance determinants. Microorganisms 2016, 4, 14. [CrossRef]

107. Lekshmi, M.; Parvathi, A.; Kumar, S.; Varela, M.F. Efflux pump-mediated quorum sensing: New avenues for modulation of antimicrobial resistance and bacterial virulence. In Biotechnological Applications of Quorum Sensing Inhibitors; Springer: Singapore, 2018; pp. 127-142. ISBN 9789811090264.

108. Alav, I.; Sutton, J.M.; Rahman, K.M. Role of Bacterial Efflux Pumps in Biofilm Formation. J. Antimicrob. Chemother. 2018, 73, 2003-2020. [CrossRef]

109. Navarro Llorens, J.M.; Tormo, A.; Martínez-García, E. Stationary Phase in Gram-Negative Bacteria. FEMS Microbiol. Rev. 2010, 34, 476-495. [CrossRef] 
110. Federle, M.J. Autoinducer-2-Based Chemical Communication in Bacteria: Complexities of Interspecies Signaling. Contrib. Microbiol. 2009, 16, 18-32.

111. Pereira, C.S.; Thompson, J.A.; Xavier, K.B. AI-2-Mediated Signalling in Bacteria. FEMS Microbiol. Rev. 2013, 37, 156-181. [CrossRef]

112. Shen, F.; Hobley, L.; Doherty, N.; Loh, J.T.; Cover, T.L.; Sockett, R.E.; Hardie, K.R.; Atherton, J.C. In Helicobacter pylori Auto-inducer-2, but not LuxS/MccAB Catalysed Reverse Transsulphuration, Regulates Motility through Modulation of Flagellar Gene Transcription. BMC Microbiol. 2010, 10, 210. [CrossRef] [PubMed]

113. Xia, X. Protein isoelectric point and Helicobacter pylori. In Bioinformatics and the Cell; Springer International Publishing: Berlin/Heidelberg, Germany, 2018; pp. 397-412.

Publisher's Note: MDPI stays neutral with regard to jurisdictional claims in published maps and institutional affiliations.

(C) 2020 by the authors. Licensee MDPI, Basel, Switzerland. This article is an open access article distributed under the terms and conditions of the Creative Commons Attribution (CC BY) license (http://creativecommons.org/licenses/by/4.0/). 